\title{
Penyuluhan Persiapan ASI Ekslusif pada Ibu Hamil Di Desa Bori Kamase Kecamatan Maros Baru Kabupaten Maros
}

\author{
${ }^{1}$ Sitti Nurana, ${ }^{2}$ Sitti Hadriyanti Hamang \\ ${ }^{1,2}$ Program Studi D3 Kebidanan, Fakultas Kesehatan Masyarakat, Universitas Muslim Indonesia \\ Korespondensi: sitti.nurana@umi.ac.id
}

\begin{abstract}
Abstrak: Persiapan Laktasi Di masa kehamilan merupakan Kegiatan yang efektif untuk meningkatkan cakupan ASI Eksklusif dan Inisiasi Menyusu Dini (IMD). Peserta diutamakan ibu hamil serta ibu-ibu kader Posyandu. Keberhasilan Pemberian ASI ekslusif sangat tergantung pada persiapan laktasi pada masa kehamilan, sering ditemukan dilapangan alasan-alasan mendasar ibu-ibu tidak memberikan ASI kepada bayinya adalah, (1) ASI belum Keluar pada hari pertama, sehingga diberikan Susu Formula sambil menunggu ASI ibu (2) ASI masih sedikit, (3) Putting susu terbenam. Beberapa Alasan diatas dapat di antisipasi di masa Kehamilan pada umur kehamilan Aterm, yaitu dengan menjelaskan kepada ibu tentang proses laktasi, kebutuhan bayi akan ASI pada awal-awal kelahiran dan perawatan payudara pada umur kehamilan Aterm, serta pemberian pemgetahuan tentang gizi seimbang yang dapat dikonsumsi selama hamil untuk membantu meningkatkan produksi ASI pada masa nifas/ atau masa menyusui, Walaupun demikian kelompok ini terbuka untuk orang orang lain yang memiliki minat yang sama, seperti suami, atau keluarga yang akan mendukung dan mendampingi ibu selama masa kehamilan sampai proses menyusui kelak. Melalui Penyuluha Persiapan Laktasi yang diberikan maka diharapkan ibu hamil dapat mempersiapkan proses Laktasi sejak masa kehamilan sebagai upaya keberhasilan pemberian ASI Ekslusif.
\end{abstract}

Kata Kunci : ASI Ekslusif, Persiapan Laktasi, ibu Hamil

\begin{abstract}
Lactation Preparation In pregnancy is an effective activity to increase exclusive breast milk coverage and early breastfeeding initiation (IMD). Participants are prioritized pregnant women as well as posyandu cadre mothers. The success of exclusive breastfeeding depends heavily on lactation preparation during pregnancy, often found in the field, the fundamental reasons mothers do not give breast milk to their babies are, (1) Breast milk has not come out on the first day, so given Formula Milk while waiting for mother's breast milk, (2) Breast milk is still a little, and (3) Nipples sink. Some of the above reasons can be anticipated in pregnancy at the age of aterm pregnancy, namely by explaining to the mother about the lactation process, the baby's need for breast milk in the early stages of birth and breast care at the age of aterm pregnancy, as well as the provision of knowledge about balanced nutrition that can be consumed during pregnancy to help increase the production of breast milk in the nifas / or lactation period, However, this group is open to others who have similar interests, such as husbands, or families who will support and accompany the mother during pregnancy until the process of breastfeeding later. Through the extension of lactation preparation given, it is expected that pregnant women can prepare the lactation process since pregnancy as an effort to successfully breastfeed exclusively.
\end{abstract}

Keywords : Exclusive Breast Milk, Lactation Preparation, Pregnant Women

\section{PENDAHULUAN}

Pemberian ASI secara eksklusif dipandang sebagai intervensi yang penting untuk mengurangi morbiditas dan mortalitas neonatal, bayi atau anak dan strategi yang baik dalam kelangsungan hidup anak. $^{1}$

Air susu ibu (ASI) merupakan asupan yang sangat baik pada seribu hari pertama kelahiran. Pemberian ASI pada bayi merupakan cara terbaik peningkatan gizi dan kualitas sumber daya manusia. ASI mengandung zat-zat gizi yang struktur dan kualitasnya sangat cocok dan mudah diserap oleh bayi. Pemberian ASI mengoptimalkan perkembangan syaraf dan otak, memberikan zat-zat kekebalan terhadap penyakit dan menunjukkan ikatan emosional antara ibu daayinya. ${ }^{2}$

Organisasi Kesehatan Dunia (WHO) merekomendasikan pemberian ASI eksklusif selama 6 bulan pertama kehidupan dan dilanjutkan sampai usia 2 tahun. ASI merupakan makanan terbaik bagi bayi 
karena mengandung semua zat gizi yang dibutuhkan bayi dalam jumlah yang sesuai dan zat imunologik yang melindungi bayi dari infeksi. Berdasarkan akumulasi bukti efek protektif ASI diantaranya melindungi terhadap penyakit menular misalnya, pencernaan dan pernafasan. Tambahan lagi, efek berkepanjangan dimana menyusui berpotensi mencegah pada beberapa hasil yang sudah diteliti yaitu mencegah kejadian obesitas pada anak, memperbaiki fungsi kognitif, mencegah karies gigi, gangguan lambung dan gangguan pernapasan. Hal ini disebabkan adanya antibodi yang terkandung dalam kolostrum ASI. Bayi yang diberi ASI dapat mengatur asupan energi berhubungan dengan respon internal dalam menyadari rasa kenyang. 3,45

Penelitian di Prancis menemukan bahwa menyusui lebih lama dikaitkan dengan perkembangan kognitif dan motorik yang lebih baik pada anak-anak usia 2-3 tahun. ${ }^{6}$ Persalinan anak tunggal di Inggris yang diberi ASI berhubungan dengan peningkatan perkembangan kognitif, khususnya pada anak yang lahir prematur di banding dengan anak yang tidak diberikan ASI. ${ }^{7}$ Beberapa nutrisi termasuk vitamin A, D, B1, B2, B6, dan B12, asam lemak, dan yodium yang diperlukan untuk pertumbuhan dan perkembangan bayi ada dalam ASI. ${ }^{8}$

Riset Kesehatan Dasar (Riskesdas) 2013 menyebutkan, hanya 30,2 \% bayi umur kurang dari 6 bulan yang mendapat ASI Eksklusif, angka ini turun dari tahun 2010 yang mencapai 31,0 \% (Riskesdas, 2010-2013). Persentase pola menyusui pada bayi umur 0 bulan 39,8\%, menyusui eksklusif 5-1 \%, menyusui parsial $55,1 \%$. Persentase menyusui eksklusif semakin menurun dengan meningkatnya kelompok umur bayi, bayi yang berumur 5 bulan menyusui eksklusif hanya 15,3\%. Secara keseluruhan gambaran ASI eksklusif di Indonesia hanya 54,3 \%, di Sulawesi selatan ASI eksklusif berkisar 66,5\%. ${ }^{9}$

Desa Borikamase adalah salah satu Desa dalam wilayah Kecamatan Maros Baru Kabupaten Maros, memiliki karakteristik topografi sebagai daerah daratan rendah dengan ketinggian 300 meter di atas permukaan laut. Jalan menuju desa ini sebagian besar masih tanah berbatu dan sebagian telah dibeton. Desa Borikamase berada 28-29 KM dari Kota Makassar. Desa Borikamase dengan Luas Wilayah 5,24 KM² dan jumlah penduduk sebanyak 3.808 jiwa.

Kegiatan ini dilakukan dengan protocol kesehatan secara ketat, ini sesuai dengan Penelitian yang menganjurkan untuk tetap memakai masker, mencuci tangan dan menjaga jarak. ${ }^{10}, 11$

\section{METODE}

\section{Persiapan}

1. Tahap izin pelaksanaan Penyulusan Persiapan Laktasi

2. Bekerja sama dengan pihak kader dan bidan untuk mengumpulkan target sasaran

3. Pesiapan tempat dan alat

4. Pelaksanaan penyuluhan, dan Pembimbingan Persiapan Laktasi

5. Menggunakan infokus untuk memfasilitasi pelaksanaan pemahaman kepada ibu hamil tentang segala hal terkait senam ibu hamil.

\section{Pelaksanaan}

1. Pemberian materi penyuluhan mengenai Persiapan dan manfaat pemberan ASI Ekslusif di Desa Borikamase

2. Praktek, Pembimbingan persiapan ASI di masa Kehamilan dan Praktek Perawatan Payudara pada Masa Kehamilan Aterm 


\section{Evaluasi}

1. Kegiatan penyuluhan akan dievaluasi dengan mengetahui seberapa besar pemahaman ibu hamil terhadap materi yang dipaparkan oleh penyaji mengenai senam ibu hamil

2. Seberapa besar ibu hamil yang dapat mempraktekkan Perawatan payudara

\section{Keberlanjutan Program}

Setelah program ini selesai, wawasan Ibu hamil tentang pentingnya persiapan ASI ekslusif sejak masa kehamilan meningkat

\section{Bentuk Partisipasi Mitra}

Bidan dan Kader berkoordinasi dengan ibu hamil dalam memfasilitasi pelaksanaan pelaksanaan Penyuluhan persiapan laktasi pada masa kehamlan yang akan dilakukan termasuk mengkoordinasi peserta, serta menyiapkan tempat untuk pelaksanaan kegiatan penyuluhan dan pelaksanaan senam ibu hamil

\section{HASIL DAN PEMBAHASAN}

Tabel 1.

Bentuk Kegiatan yang Telah Dilakukan dalam Pengabdian Kepada Masyarakat Di Desa Bori Kamase, Kecamatan Maros Baru, Kabupaten Maros

\begin{tabular}{|c|c|c|c|}
\hline No & Bentuk Kegiatan & Waktu & Tempat \\
\hline 1. & $\begin{array}{l}\text { Persiapan (Survey lokasi, identifikasi masalah, } \\
\text { penyusunan proposal, seminar proposal) }\end{array}$ & Januari 2021 & Desa Borikamase, Maros \\
\hline 2. & $\begin{array}{l}\text { Sosialisasi (koordinator dengan mitra dan pemerintah } \\
\text { setempat) }\end{array}$ & Januari 2021 & Desa Borikamase, Maros \\
\hline 4. & Persiapan materi, ATK dll & Februari 2021 & Desa Borikamase, Maros \\
\hline 5. & $\begin{array}{l}\text { a. Pelaksanaan Penyuluhan Persiapan Laktasi pada } \\
\text { Masa kehamilan } \\
\text { b. Evaluasi setelah Penyuluhan }\end{array}$ & $\begin{array}{l}\text { 16-26 Februari } \\
2021\end{array}$ & Desa Borikamase, Maros \\
\hline 6. & Evaluasi Kegiatan & Februari 2021 & Desa Borikamase, Maros \\
\hline 7. & Penyusunan laporan & Maret 2021 & Makassar \\
\hline
\end{tabular}

\section{Peserta/Persiapan}

1. Peserta yang mengikuti kegiatan ini adalah ibu hamil yang usia kehamilannya memasuki trimester 3 di Desa Borikamase Maros yang dipilih berdasarkan perwakilan dari masing-masing setiap RT.

2. Memberikan penyuluhan Kesehatan persiapan laktasi sejak masa kehamilan, setelah itu melakukan sesi tanya jawab

\section{Evaluasi Kegiatan}

1. Melakukan diskusi langsung dengan mitra tentang tanggapan terhadap yang telah dilakukan serta mendengar masukan dari mitra tentang harapan-harapan yang diinginkan untuk kesinambungan kegiatan.

2. Antusias para Ibu hamil dalam mempersiapkan pemberian ASI Ekslusif pada bayinya kelak

3. bidan dan Kader juga sangat aktif dalam kegiatan Penyuluhan ini dan hadir hingga akhir kegiatan

This is an open-access article under the CC BY 4.0 International License

(C) Idea Pengabdian Masyarakat (2021)

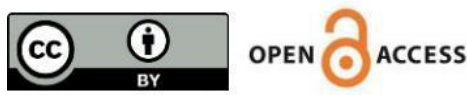




\section{Permasalahan dan Hambatan}

1. Belum dapat melakukan pengukuran cakupan dalam keberhasilan persiapan dan keberhasilan pemberian ASI Ekslusif dikarenakan membutuhkan waktu yang cukup lama

2. Waktu Ibu Hamil yang sulit untuk disesuaikan dengan waktu yang kosong karena aktivitas yang lebih banyak berhubungan dengan kegiatan keluarga.
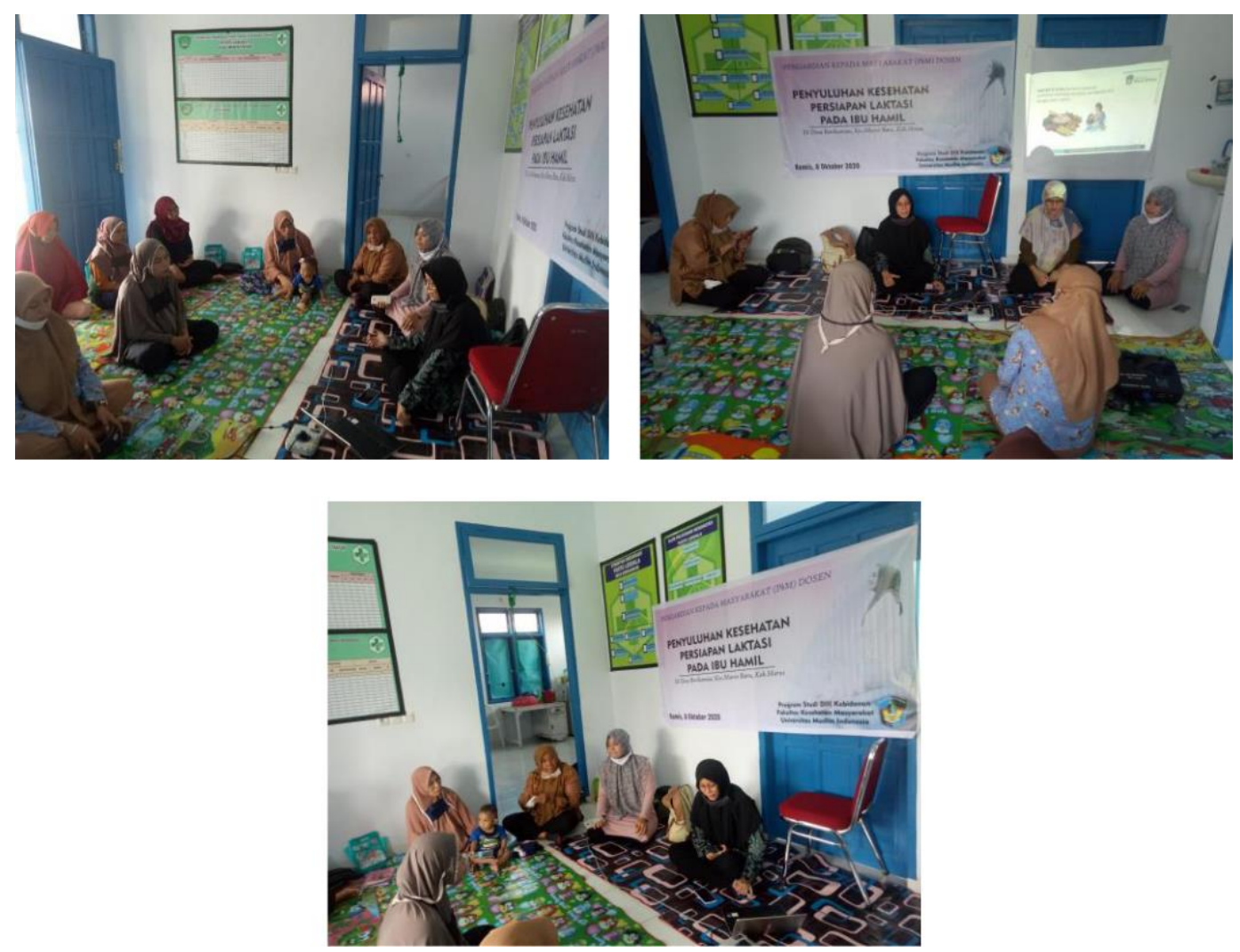

\section{KESIMPULAN}

Gambar.(1,2,3), Dokumentasi Kegiatan Penyuluhan

Kegiatan terlaksana sesuai dengan tujuan dan harapan, kegiatan ini mendapat sambutan baik dari pemerintah setempat dan antusiasme yang tinggi dari ibu hamil, kegiatan ini dapat menambah pengetahuan dan kemampuan ibu hamil dalam mempersiapkan proses laktasi guna mendukung terlaksananya Pemberian ASI Ekslusif.

Diharapkan peran serta masyarakat, khusunya ibu hamil untuk mempersiapkan pemberian laktasi sejak masa kehamilan guna mendukung terlaksananya pemberian ASI Ekslusif dan kepada mitra agar dapat mendukung program pengabdian kepada masyarakat, khususnya pada persiapan laktasi selama masa kehamilan demi keberhasilan program pemberian ASI ekslusif.

\section{UCAPAN TERIMAKASIH}

Tim Peneliti mengucapkan banyak terimakaish kepada semua pihak yang telah membantu baik secara langsung maupun tidak secara langsung. 


\section{DAFTAR PUSTAKA}

1. Mo O, As $\mathrm{U}$, Ahmed $\mathrm{H}$. Knowledge and practice of exclusive breastfeeding in Kware, Nigeria. Afr Health Sci. 2011;11(3):518-23.

2. Rusli U. Inisiasi menyusui dini plus ASI eksklusif. Puspa Swara; 2008.

3. Kramer M., Kakuma R. Optimal duration of exclusive breastfeeding. Cochrane database Syst Rev. 2012;

4. Sutoo B, Anggraini D. Makanan sehat pendamping ASI. Jakarta: Demedia; 2010.

5. Horta B., Victoria C., (WHO) WHO. Short-term effects of breastfeeding. 2013;

6. Bernard J., DeAgostini M, Forhan A, Alfaiate T, Bonet $M$, Champion V, et al. Breastfeeding duration and cognitive development at 2 and 3 years of age in the EDEN mother-child Cohort. J Pediatr. 2013;163(1):36-42.

7. Quigley MA, Poulsen G, Boyle E, Wolke D, Field D, Alfirevic Z, et al. Early term and late preterm birth are associated with poorer school performance at age 5 years: A cohort study. Arch Dis Child Fetal Neonatal Ed. 2012;97(3):1-8.

8. Valentine $C$, Wagner C. Nutritional management of the breastfeeding dyad. Pediatr Clin. 2013;60(1):261-74.

9. Kementrian Kesehatan. Profil Kesehatan Indonesia Tahun 2013. Jakarta: Kementerian Kesehatan RI. 2014. 507 p.

10. Amir H, Taqiyah Y. Pengaruh covid-19 kepada masyarakat. Pros Has Pengabdi Masy Tahun 2021. 2021;1-5.

11. Amir $\mathrm{H}$, Agus AI, Irfan M, Bima M, Ad IA, Hafid MF, et al. Penerapan 3M dalam Mencegah Penularan Covid-19 di Desa Lonjoboko Kabupaten Gowa. 2021;1(01):1-4. Available from: https://ideapengabdianmasyarakat.ideajournal.id/index.php/ipm/article/view/1/1 